\title{
IMPLEMENTASI PENGGUNAAN OPENCV PADA FACE RECOGNITION UNTUK SISTEM PRESENSI PERKULIAHAN MAHASISWA
}

\author{
${ }^{1}$ Banu Santoso, ${ }^{2 *}$ Ryan Putranda Kristianto \\ ${ }^{1}$ Teknik Komputer, Fakultas Ilmu Komputer, Universitas AMIKOM Yogyakarta, Indonesia \\ ${ }^{2}$ Informatika, Fakultas Ilmu Komputer, Universitas AMIKOM Yogyakarta, Indonesia \\ Email: banu@amikom.ac.id, ryanputrandak@amikom.ac.id \\ *) Corresponding Author: Ryan Putranda Kristianto
}

(Diterima: 12 Maret 2020,direvisi: 25 April 2020, disetujui: 28 April 2020 )

\begin{abstract}
The lecture data on college lectures into a reference in demonstrating the credibility of each student used by the lecturers as data for the student's value as well as the evaluation of the success of learning activities Teaching in the lecture, but there are some examples of cases, associated with the data of the student's presence that is currently involved in education or lectures is the phenomenon of "absent point". In addition, other problems also arise from the lecturers and administration officers, the difficulties in monitoring student attendance and efforts to validate the presences data because of the number of student data is so much. Therefore in this study submitted a system to reduce the level of fraud in filling the list of the presences and effectiveness of data processing students by using the system implementation of Face Recognition based on Open CV method with The Haar Cascade Classifier and Local Binary Patterns Histograms (LBPH) methods. The results of this Face Recognition study successfully detected when all the users that were reidentified were registered to the system, with the optimal range of Face Recognition to be detected to $150 \mathrm{~cm}$. While Face Recognition is unsuccessful Detected when there is an obstacle covering the face objects and distances exceeding from $150 \mathrm{~cm}$.
\end{abstract}

Keywords: Face Recognition, OpenCV, student presences, Haar Cascade, LBPH

\begin{abstract}
ABSTRAK
Data presensi perkuliahan pada perguruan tinggi menjadi suatu acuan dalam menunjukkan kredibilitas setiap mahasiswa yang digunakan oleh para dosen sebagai data untuk pemberian nilai mahasiswa sekaligus sebagai bahan evaluasi keberhasilan kegiatan belajar mengajar dalam perkuliahan, namun ada beberapa contoh kasus, terkait dengan data presensi mahasiswa yang saat ini marak terjadi pada dunia pendidikan atau perkuliahan adalah fenomena "Titip Absen". Selain itu, masalah lainnya juga muncul dari pihak dosen dan pegawai tata usaha yakni kesulitan dalam memonitor kehadiran mahasiswa serta upaya memvalidasi data presensi karena jumlah data mahasiswa yang begitu banyak. Oleh karena itu dalam penelitian ini diajukan suatu sistem untuk mengurangi tingkat kecurangan dalam pengisian daftar presensi dan efektivitas pengolahan data mahasiswa dengan menggunakan sistem penerapan metode Face Recognition berbasis Open CV dengan metode Haar Cascade Classifier dan Local Binary Patterns Histograms (LBPH). Hasil penelitian Face Recognition ini berhasil mendeteksi apabila semua pengguna yang dipresensikan telah terdaftar ke sistem, dengan jarak jangkauan optimal Face Recognition agar terdeteksi sampai $150 \mathrm{~cm}$. Sedangkan Face Recognition tidak berhasil terdeteksi apabila ada obstacle menutupi objek wajah dan jarak melebihi dari $150 \mathrm{~cm}$.
\end{abstract}

Kata Kunci: Face Recognition, OpenCV, Presensi Mahasiswa, Haar Cascade, LBPH.

\section{PENDAHULUAN}

Seiring dengan perkembangan zaman saat ini masyarakat dituntut untuk berproses lebih cepat dalam segala hal dikarenakan teknologi berkembang begitu cepat dengan berbagai inovasi-inovasi yang bermunculan dan penerapannya, yang dimana sangat membantu aktivitas keseharian masyarakat serta penerapan teknologi canggih ini sangat dirasakan di semua aspek, salah satunya di bidang akademik perkuliahan yang bertujuan mempermudah proses pelayanan akademik, salah satu

Santoso, Implementasi Penggunaan Opencv Pada Face Recognition Untuk Sistem Presensi Perkuliahan Mahasiswa 
pemanfaatan teknologi informasi tersebut adalah sistem presensi perkuliahan pada perguruan tinggi. Data presensi yang ada digunakan sebagai acuan untuk menunjukkan kredibilitas atau kejujuran setiap mahasiswa [1], selain itu digunakan oleh para dosen sebagai data untuk pemberian nilai mahasiswa dan juga sebagai bahan evaluasi keberhasilan kegiatan belajar mengajar dalam perkuliahan. Kehadiran sangatlah penting bagi mahasiswa yang diwajibkan untuk menghadiri perkuliahan minimal $80 \%$, yang dimana menentukan mahasiswa tersebut layak untuk mengikuti ujian semester atau tidak, selain itu kebanyakan dosen menjadikan itu sebagai komponen penilaian [2].

Meskipun beberapa universitas masih menggunakan sistem presensi kelas yang masih menggunakan tanda tangan secara konvensional dan juga menggunakan kode batang (barcode) yang terdapat pada Kartu Tanda Mahasiswa (KTM) sebagai input data presensi, namun kedua metode tersebut dinilai kurang efektif untuk menunjang kegiatan pembelajaran mahasiswa. Beberapa contoh kasus yang sering terjadi pada dunia perkuliahan terkait dengan data presensi mahasiswa yang sering menimbulkan banyak kontroversi adalah fenomena "Titip Absen" atau umum disebut TA.

Masalah tersebut tidak hanya muncul dari pihak mahasiswa tetapi juga pihak akademik kampus yang juga mengalami kesulitan dalam hal administrasi dan manajemen data kampus. Maka dari itu diperlukan suatu solusi yang menggunakan suatu inovasi baru terkait dengan presensi perkuliahan guna mengurangi tingkat kecurangan dalam pengisian daftar presensi dan efektivitas pengolahan data mahasiswa dengan menggunakan sistem presensi dengan metode face recognition. Sistem presensi dengan metode face recognition merupakan suatu mekanisme presensi dengan teknik biometrik pengenalan wajah sebagai simbol identitas dengan menggunakan alat yang terkomputerisasi [3].

Penerapan sistem presensi dengan metode face recognition ini menggunakan konsep computer vision [4] yang merupakan ujung tombak bidang ilmu komputer dengan tujuan untuk mengaktifkan komputer dalam memahami apa yang terjadi pada suatu objek di suatu gambar. Model face recognition secara real time [5] akan lebih memudahkan pengguna dalam melakukan presensi dan juga menghindari adanya manipulasi data presensi. Sehingga mampu mencegah mahasiswa untuk memalsukan kehadirannya dan lebih menghemat waktu dalam pengambilan presensi, oleh karena itu berdasarkan permasalahan di atas maka peneliti membuat suatu perancangan presensi yang dinilai lebih efektif dan berdaya guna yang mampu mengurangi kesalahan dalam proses identifikasi melalui penerapan metode face recognition berbasis OpenCV dengan metode Haar Cascade Classifier dan Local Binary Patterns Histograms (LBPH).

Tujuan dari penelitian yang dilakukan ini adalah Memudahkan proses presensi perkuliahan dan pemantauan dengan menggunakan teknologi face recognition secara real time yang berbasis OpenCV dengan metode Haar Cascade Classifier dan Local Binary Patterns Histograms (LBPH). Sedangkan manfaat dari penelitian ini adalah memberikan solusi untuk pengawasan kehadiran dalam perkulihan mahasiswa sehingga proses belajar dan mengajar menjadi lebih kondusif.

\section{TINJAUAN PUSTAKA}

Berbagai penelitian telah dilakukan sebelumnya terkait dengan penerapan sistem presensi yang dipadukan dengan beberapa perangkat atau metode baru sehingga mampu merancang suatu sistem yang memberikan kontribusi tersendiri serta inovasi-inovasi baru pada setiap sistem perangkat yang dihasilkan.

Berdasarkan Ikhtisar Penelitian Tabel 1 terdapat beberapa perbedaan-perbedaan metode yang diusulkan sebagai kontribusi positif dalam penelitian. Untuk penelitian yang dilakukan oleh Lodha, dkk [6], menyajikan aplikasi presensi kehadiran dengan menggunakan Bluetooth dan RFID. Teknologi ini menggunakan tag elektronik untuk mengidentifikasi nirkabel secara otomatis, dengan perangkat berkemampuan Bluetooth. Aplikasi kehadiran mahasiswa berbasis Bluetooth dapat mempersingkat waktu serta mengurangi faktor kesalahan manusia yang sering pada presensi manual. Aplikasi ini juga menghasilkan data statistik kehadiran mahasiswa sehingga memudahkan manajemen sekolah mengambil keputusan lebih lanjut. Keunggulan utama dari sistem ini diantara lain yaitu konsumsi daya rendah, transfer data tinggi, ukuran chip kecil dan biaya rendah serta implementasi perangkat tersebut bisa diterapkan mudah. Berikut Tabel 1 yang menyajikan hasil penelitian dari peneliti sebelumnya yang dimana berkaitan dengan pemantauan presensi kehadiran. 
Tabel 1 Ikhtisar Penelitian

\begin{tabular}{|c|c|c|c|}
\hline Peneliti/Tahun & Lokasi & Kontribusi Penelitian & Metode \\
\hline $\begin{array}{l}\text { Lodha, } \\
\text { dkk/ } 2015[6]\end{array}$ & Universitas & $\begin{array}{ll}\text { Mengurangi } & \text { kecurangan } \\
\text { presensi kehadiran } & \text { mahasiswa } \\
\text { di Universitas } & \end{array}$ & Bluetooth dan RFID. \\
\hline $\begin{array}{l}\text { Noor, dkk/ } \\
2015[7]\end{array}$ & Universitas & $\begin{array}{ll}\text { Mengurangi } & \text { kecurangan } \\
\text { presensi kehadiran } & \text { mahasiswa } \\
\text { di Universitas } & \end{array}$ & Android dan RFID. \\
\hline $\begin{array}{l}\text { Chaniago, } \\
\text { dkk/2016 [8] }\end{array}$ & Sekolah & $\begin{array}{l}\text { Mengurangi kecurangan dalam } \\
\text { presensi siswa di sekolah. }\end{array}$ & SMS Gateway dan Barcode. \\
\hline $\begin{array}{l}\text { Dhanalakshmi, } \\
\text { dkk/2017 [9] }\end{array}$ & Sekolah & $\begin{array}{l}\text { Mengurangi ketidakteraturan } \\
\text { presensi kehadiran Siswa }\end{array}$ & $\begin{array}{l}\text { Fingerprint dan GSM (Short } \\
\text { Message Service/ SMS). }\end{array}$ \\
\hline $\begin{array}{l}\text { Vantová, } \\
\text { dkk/ 2017 [10] }\end{array}$ & Universitas & $\begin{array}{l}\text { Mengurangi manipulasi presensi } \\
\text { kehadiran mahasiswa di } \\
\text { Universitas }\end{array}$ & $\begin{array}{l}\text { Smartphone (Android), Radio } \\
\text { Frequency Identification } \\
\text { (RFID), dan Near Field } \\
\text { Communication (NFC). }\end{array}$ \\
\hline Penelitian Ini & Universitas & $\begin{array}{lr}\text { Mengurangi } & \text { kecurangan } \\
\text { presensi kehadiran } & \text { mahasiswa } \\
\text { di Universitas } & \end{array}$ & $\begin{array}{l}\text { Face Recognition secara real } \\
\text { time berbasis OpenCV } \\
\text { dengan metode Haar Cascade } \\
\text { Classifier dan Local Binary } \\
\text { Patterns Histograms (LBPH) }\end{array}$ \\
\hline
\end{tabular}

Penelitian ini dilakukan oleh Noor, dkk [7], dengan mengubah metode konvensional yang masih diadopsi di beberapa institusi pendidikan, seperti dosen memanggil nama mahasiswa satu per satu atau dengan mengambil tanda tangan dari setiap mahasiswa untuk menentukan presensi kehadiran. Saat ini, metode yang lebih baik juga sudah digunakan, yaitu dengan mengandalkan sistem untuk mencatat kehadiran mahasiswa secara semi-otomatis. Misal sistem berbasis RFID atau biometrik. Sistem seperti itu telah menjadi solusi untuk masalah yang ada, namun kelemahannya adalah biaya tambahan pemeliharaan perangkat keras. Aplikasi ini, setelah diinstal dapat digunakan untuk mengunduh daftar mahasiswa dari server web. Berdasarkan daftar mahasiswa yang diunduh, perangkat kemudian akan bertindak seperti pemindai untuk memindai setiap kartu mahasiswa satu per satu dan mengonfirmasi serta memverifikasi keberadaan mahasiswa. Sedangkan perangkat kamera digunakan sebagai sensor yang membaca barcode pada kartu mahasiswa. Daftar kehadiran yang diperbarui kemudian diunggah ke database online dan juga dapat disimpan sebagai file yang akan ditransfer ke PC.

Penelitian ini dilakukan oleh Chaniago, dkk [8], menyajikan aplikasi kehadiran siswa berbasis aplikasi SMS Gateway yang dibuat untuk memastikan bahwa siswa menghadiri kelas, dengan langkah-langkah sebagai berikut yaitu siswa harus menyerahkan kartu identitas kepada guru yang bertugas, kemudian guru memindai barcode yang tercetak pada kartu, dan akhirnya data akan disimpan dalam database secara otomatis. Aplikasi ini menyediakan layanan bagi orang tua untuk mencari informasi secara mingguan dan bulanan. Aplikasi ini juga dapat menjadi bahan pertimbangan dalam mengambil keputusan untuk para pelaku dengan mengunduh data kehadiran siswa dalam format file Microsoft Excel. Implementasi aplikasi berbasis SMS gateway untuk kehadiran siswa di sekolah diharapkan menjadi solusi untuk masalah ketidakhadiran siswa karena bolos sekolah. Dengan dibangunnya sistem ini, orang tua dapat memantau anak-anak mereka dengan memperoleh informasi dalam bentuk pesan teks yang dikirim dari manajemen sekolah tentang keberadaan anak-anak mereka di sekolah. 
Penelitian ini dilakukan oleh Dhanalakshmi, dkk [9], menyajikan penelitian dengan menggunakan Fingerprint dan modul GSM/ GPRS. Pada sistem kehadiran biometrik sidik jari dirancang dan diimplementasikan untuk memantau waktu nyata yang efisien serta transparansi dalam pengelolaan kehadiran siswa yang sesungguhnya menggunakan terminal sidik jari nirkabel berbasis GSM - Wireless Fingerprint Terminals (WFTs). Sistem ini cocok jika diterapkan di institusi pendidikan. Setiap individu memiliki pola sidik jari yang unik sehingga memotivasi penggunaannya untuk melakukan autentikasi biometrik dan di verifikasi untuk menemukan kehadiran siswa di institut tersebut. Ada dua pendekatan untuk mengotentikasi sidik jari yang diambil dalam proses verifikasi yaitu, pendekatan pertama menggunakan basis data yang dibuat oleh organisasi itu sendiri dan pendekatan kedua menggunakan Aadhaar Central Identification Repository (CIDR). Dengan menggunakan kehadiran asli WFT dari siswa dapat dicatat, dipantau dan dipelihara tanpa ada campur tangan dari manusia. Laporan kehadiran dapat secara otomatis dikirim langsung ke siswa dan nomor ponsel orang tua mereka melalui SMS sehingga memberikan transparansi selain itu untuk mempromosikan manajemen sistem absensi yang efisien dan meningkatkan kualitas akademik.

Penelitian ini dilakukan oleh Vantová, dkk [10], menyajikan aplikasi untuk mengelola sistem presensi dengan membuat daftar kehadiran. Aplikasi administrasi ini dibuat untuk menghindari manipulasi melalui sistem daftar kehadiran, selain itu menyediakan cara yang aman dan dapat diandalkan untuk mengevaluasi kehadiran mahasiswa pada kuliah tertentu serta menyelesaikan tugas. Aplikasi ini menggunakan teknologi NFC pada smartphone dan kartu RFID sebagai kartu mahasiswa, yang kepemilikannya wajib untuk setiap mahasiswa di universitas. Teknologi NFC memiliki kemampuan untuk merekam identitas mahasiswa pada kartu mahasiswa.

Sedangkan dalam penelitian ini menggunakan pemodelan perancangan sistem presensi kehadiran mahasiswa di universitas dengan memanfaatkan face recognition secara real time berbasis OpenCV dengan metode Haar Cascade Classifier dan Local Binary Patterns Histograms (LBPH), sehingga pemodelan sistem tersebut dapat mengurangi kecurangan atau manipulasi dalam sistem presensi. Selain itu pengolahan data presensi berguna bagi sistem penilaian terhadap mahasiswa dan monitoring kehadiran mahasiswa setiap pertemuan kuliah kelas teori maupun praktikum.

\section{A. OpenCV}

OpenCV [4] merupakan library computer vision yang open source dan sangat populer serta digunakan untuk memproses dan menganalisis pada images. Terdapat lebih 2500 algoritma optimasi yang bisa digunakan untuk memanipulasi untuk memproses dan mengedit images dengan menggunakan $O p e n C V$. Dengan adanya $O p e n C V$ mendukung berbagai bahasa pemprograman seperti $C, C++$, Python, Java, dan PHP. Beberapa aplikasi OpenCV yang bisa diterapkan diantaranya adalah Interaksi Manusia Komputer (HCI), Identifikasi dan Pengenalan Objek, Deteksi [11] dan Pengenalan Wajah [12], Pengenalan Gestur, Tracking Gerakan, Proses pada image, dan Mobile Robotics.

\section{B. Haar Cascade Classifier}

Algoritme Haar cascade [13] digunakan untuk melakukan proses pendeteksian wajah atau objek yang berupa gambar digital. Algoritme ini menampilkan fungsi matematika yang berupa kotak dengan menampilkan nilai RGB pada setiap pixel, setelah itu Viola-Jones mengembangkan algoritme ini, dimana setiap kotak diproses dan menghasilkan beberapa nilai yang berupa daerah gelap dan terang. Dan nilai-nilai tersebut yang akan dijadikan sebagai dasar dalam pemrosesan gambar, sehingga dikenal dengan Haar-Like Feature [14].

Proses perhitungan nilai fitur dari Algoritma Haar yaitu dengan mengurangkan nilai pixel pada daerah putih dengan daerah hitam. Algoritme ini menggunakan Integral Image dari sebuah citra gambar dalam bentuk grayscale yang tiap nilai pixel akan dijumlahkan dari nilai pixel kiri atas menuju ke kanan bawah. Untuk metode Cascade Classifier [15] seperti pada Gambar 1 menggunakan beberapa langkah untuk menentukan dan menghitung ulang nilai Haar Feature sehingga menghasilkan nilai yang lebih akurat. Langkah klasifikasi pertama meliputi sub citra yang diklasifikasi dengan satu fitur, namun bila tidak memenuhi akan kriteria akan ditolak hasilnya. Pada Klasifikasi kedua meliputi klasifikasi kembali pada sub citra sehingga memperoleh nilai threshold yang ditentukan. Sedangkan pada klasifikasi ketiga meliputi sub citra yang berhasil atau lolos dan mendekati nilai citra yang sesungguhnya.

Santoso, Implementasi Penggunaan Opencv Pada Face Recognition Untuk Sistem Presensi Perkuliahan Mahasiswa 


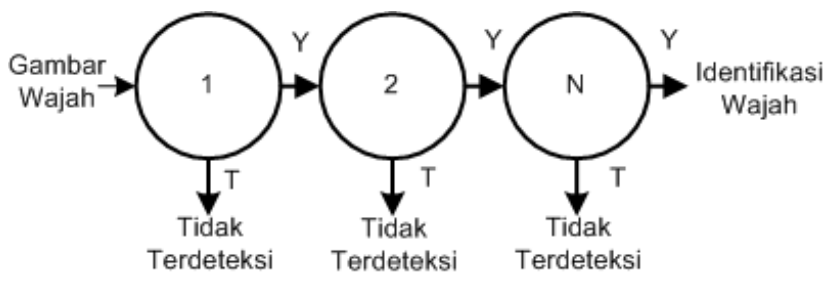

Gambar 1 Metode deteksi cascade classifier

\section{Local Binery Pattern Histogram $($ LBPH $)$}

Pengenalan wajah dimulai dari hasil deteksi streaming Webcam dengan diperoleh dari hasil training Haar Cascade yang akan dicocokkan dengan Algoritma Local Binary Pattern Histogram $(L B P H)$ [16]. Pencocokan dengan metode LBPH menggunakan nilai biner histogram yang telah diekstrasi dari gambar untuk mendapatkan nilai prediksi dalam mengidentifikasikan pemilik wajah.

\section{METODE PENELITIAN}

Ada beberapa alat dan bahan berupa perangkat keras dan perangkat lunak yang digunakan dalam penelitian ini. Bahan dan alat yang digunakan pada penelitian ini meliputi perangkat keras dan perangkat lunak. Perangkat keras yang digunakan dalam penelitian ini adalah CPU $1.6 \mathrm{GHz}$ Intel Core i5-8250U, Memori DDR 16 GB, NVIDIA GeForce 940MX, Sistem Operasi Windows 10 serta penyimpanan berupa SSD dengan kapasitas 250 GB. Perangkat lunak yang digunakan dalam penelitian ini adalah Anaconda versi 5.1, Spyder versi 3.4.2, Jupyter Notebook 4.3.1, Python versi 2.7.14, OpenCV 3.4, Numpy 1.17.4, Pillow 6.2.1 serta Pustaka face recognition.

Metode yang digunakan dalam penelitian ini adalah melalui studi literatur, perancangan sistem, implementasi sistem, pengujian sistem serta analisis hasil pengujian sistem. Pada penelitian ini akan menerapkan teknologi Face Recognition berbasis Open CV dengan metode Haar Cascade Classifier dan Local Binary Patterns Histograms

Selanjutnya, jalan penelitian dimulai dari penentuan ide yang nantinya akan dikaji pada proses studi pustaka. Kemudian pada studi pustaka dilakukan proses pengkajian dari berbagai sumber yang membahas tentang penelitian serupa. Lalu dilakukan perumusan masalah yang ingin diselesaikan. Masalah yang diselesaikan adalah masalah yang masih belum diselesaikan oleh peneliti sebelumnya. Setelah itu tujuan penelitian ditentukan dan dirancang percobaan yang ingin dilakukan. Kemudian dilakukan percobaan untuk memperoleh fakta-fakta yang diperlukan untuk menyelesaikan masalah yang ingin diselesaikan. Lalu fakta-fakta tersebut dianalisis untuk menghasilkan kesimpulan yang menjadi jawaban atas tujuan penelitian.

\section{HASIL DAN PEMBAHASAN}

\section{A. Perancangan Sistem}

Diagram blok perancangan sistem ini dapat dilihat pada Gambar 2. Aplikasi presensi kehadiran perkuliahan mahasiswa menggunakan face recognition secara real time berbasis OpenCV dengan metode Haar Cascade Classifier dan Local Binary Patterns Histograms (LBPH). Cara kerja sistem adalah mendeteksi objek atau wajah di ruangan kelas dengan menggunakan WebCam pada PC Server. 


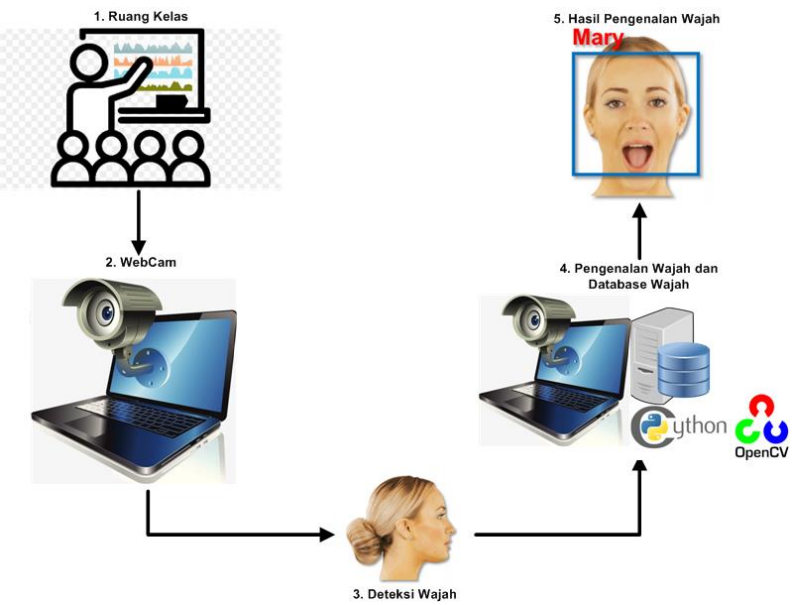

Gambar 2 Arsitektur sistem

Pada Gambar 3 menunjukkan tahap awal berupa pendeteksian wajah secara real time dengan di konversi terlebih dahulu ke citra grayscale sehingga dapat diolah menggunakan metode filter Haar Cascade. Setelah itu objek berupa wajah akan bisa terdeteksi dengan ditandai rectangle wajah berwarna putih. Agar wajah mudah dikenali maka diperlukan pengumpulan data dari beberapa wajah mahasiswa atau dosen yang direkam oleh WebCam dan hasilnya menjadi dataset wajah mahasiswa di kelas perkuliahan dengan berbagai pose atau sudut wajah sebanyak 30 kali.

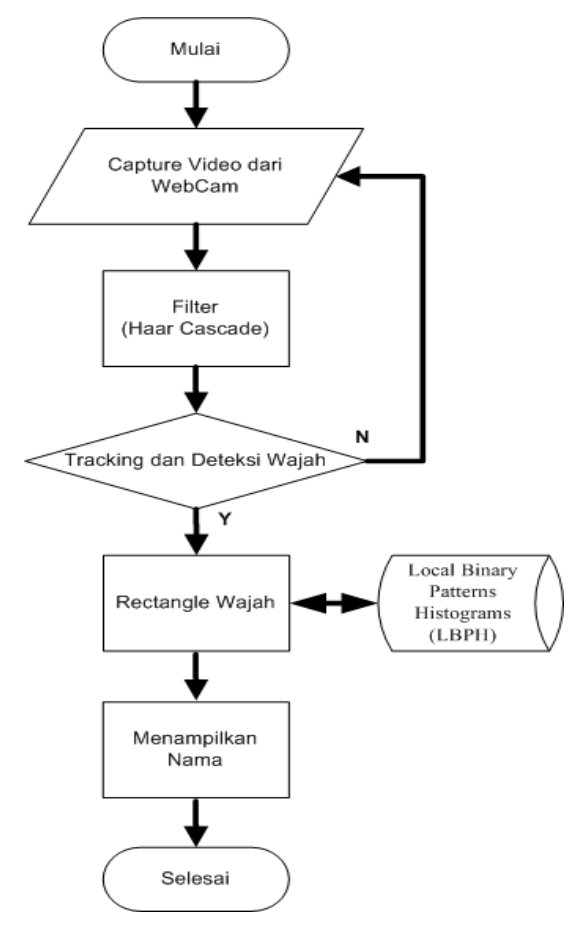

\section{Gambar 3 Flowchart sistem}

Setelah itu dari dataset wajah mahasiswa akan di training dan recognizer dengan metode Local Binary Patterns Histograms (LBPH) untuk mendapatkan pola unik berupa face encoding dengan pendekatan nilai jarak histogram. Dari proses LBPH akan mengenal wajah (face recognition) mahasiswa tersebut dengan menampilkan nama dan program studi mahasiswa. Setelah proses face recognition, maka data mahasiswa tersebut akan tersimpan di server sebagai bukti presensi kehadiran pada perkuliahan. 


\section{B. Implementasi Sistem}

WebCam mengambil video atau gambar secara real time yang di proses terlebih dahulu menjadi gambar grayscale atau citra RGB. Setelah itu citra tersebut akan diolah menggunakan metode pendeteksian wajah berupa Haar Cascade. Wajah yang terdeteksi ditunjukkan berupa garis bujur sangkar ROI (Region of Interest). Gambar 4 merupakan gambar capture dari WebCam yang langsung diubah menjadi gambar grayscale.

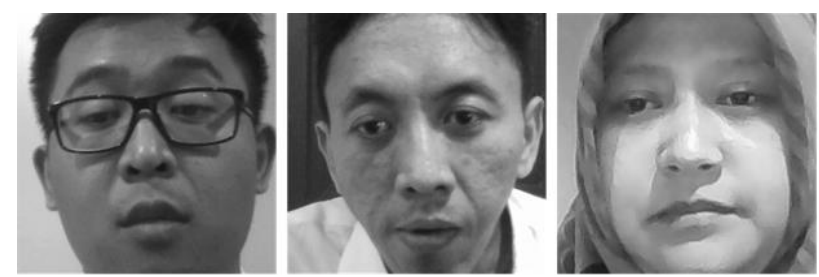

\section{Gambar 4 Citra grayscale}

Pada penelitian ini menggunakan parameter pengujian berupa pengenalan beberapa wajah dalam satu frame dan pengenalan wajah dengan berbagai halangan (obstacle) serta pengenalan wajah dengan jarak jangkauan WebCam.

\section{Pengujian Sistem}

Pada Gambar 5 dan Gambar 6 merupakan hasil deteksi dan pengenalan satu wajah dan beberapa wajah dalam satu frame. Pada Tabel 2 menunjukkan hasil percobaan bahwa sistem dapat mendeteksi dan mengenali objek wajah dari satu atau beberapa objek wajah dalam satu frame yang dihasilkan dengan baik.

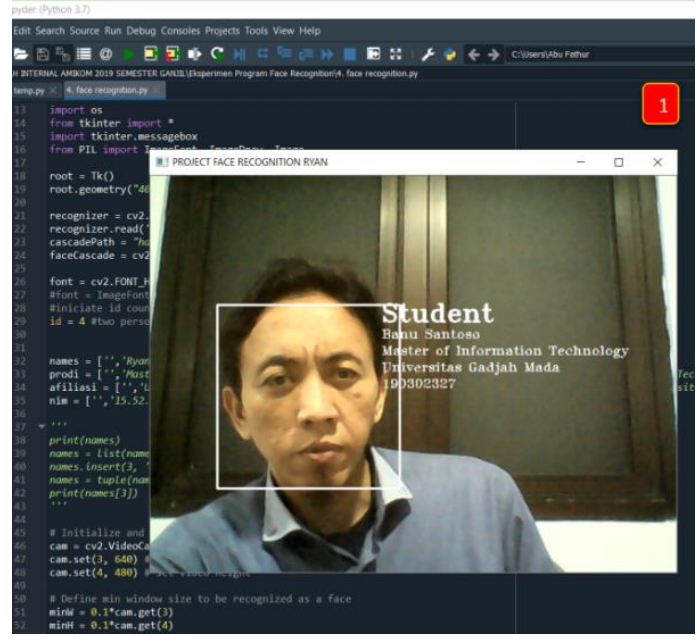

\section{Gambar 5 Tracking dan deteksi pengenalan satu wajah}

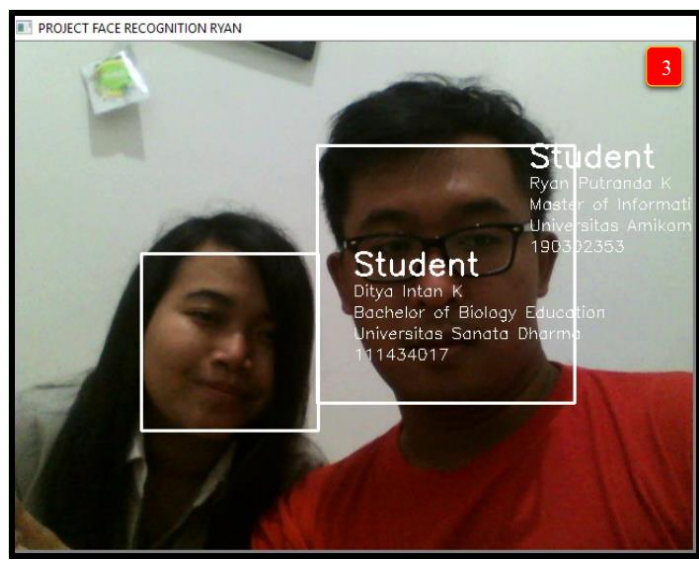

Gambar 6 Tracking dan face recognition dengan multiply face

Santoso, Implementasi Penggunaan Opencv Pada Face Recognition Untuk Sistem Presensi Perkuliahan Mahasiswa 
Tabel 2 Parameter pada Single/ Multiple Face

\begin{tabular}{ll}
\hline No & Parameter Single / Multiple Wajah \\
\hline $\mathbf{1}$ & Satu Orang dapat terdeteksi dan Pengenalan Wajah dalam 1 frame \\
\hline $\mathbf{2}$ & Enam Orang dapat terdeteksi dan Pengenalan Wajah dalam 1 frame \\
\hline $\mathbf{3}$ & 10 Orang dapat terdeteksi dalam 1 frame \\
\hline $\mathbf{4}$ & 15 Orang dapat terdeteksi dalam 1 frame \\
\hline
\end{tabular}

Pada Gambar 7 dan Tabel 3 menunjukkan hasil percobaan bahwa sistem tidak dapat mendeteksi maupun mengenali objek wajah dengan memberikan penghalang berupa kertas, spidol/ pena dan penggaris untuk menutupi sebagian wajah.

Tabel 3 Parameter Penghalang

\begin{tabular}{lc}
\hline No & Parameter Penghalang \\
\hline $\mathbf{1}$ & Wajah tidak terdeteksi dengan penghalang kertas menutupi sebagian wajah \\
\hline $\mathbf{2}$ & Wajah sempat tidak terdeteksi dengan penghalang spidol/ pena \\
\hline $\mathbf{3}$ & Wajah sempat tidak terdeteksi dengan penghalang penggaris \\
\hline
\end{tabular}

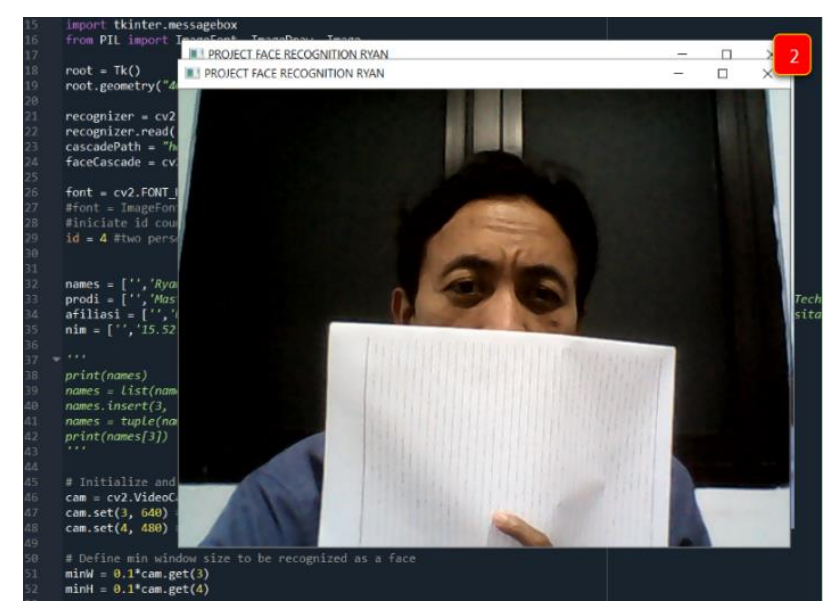

Gambar 7 Wajah tidak terdeteksi

Pada Gambar 8, Gambar 9 dan Tabel 4 menunjukkan hasil percobaan bahwa sistem masih dapat mendeteksi maupun mengenali objek wajah dengan berbagai jarak yang masih terjangkau dengan WebCam. Pada jarak $46 \mathrm{~cm}$ sampai dengan $150 \mathrm{~cm}$, WebCam masih mendeteksi dan mengenali wajah dalam satu frame dengan kondisi baik. Sedangkan pada jarak $204 \mathrm{~cm}$ maka WebCam dapat mendeteksi namun tidak ada pengenalan wajah dalam satu frame.

Tabel 4 Parameter Jarak Jangkauan

\begin{tabular}{ll}
\hline No & \multicolumn{1}{c}{ Parameter Jarak Jangkauan } \\
\hline $\mathbf{1}$ & Jarak $46 \mathrm{~cm}$ dapat terdeteksi dan Pengenalan Wajah dalam 1 frame \\
\hline $\mathbf{2}$ & Jarak 67 cm dapat terdeteksi dan Pengenalan Wajah dalam 1 frame \\
\hline $\mathbf{3}$ & Jarak 103 cm dapat terdeteksi dan Pengenalan Wajah dalam 1 frame \\
\hline $\mathbf{4}$ & Jarak 150 cm dapat terdeteksi dan Pengenalan Wajah dalam 1 frame \\
\hline $\mathbf{5}$ & $\begin{array}{l}\text { Jarak 204 cm dapat terdeteksi namun tidak ada pengenalan Wajah } \\
\text { dalam 1 frame }\end{array}$ \\
\hline
\end{tabular}




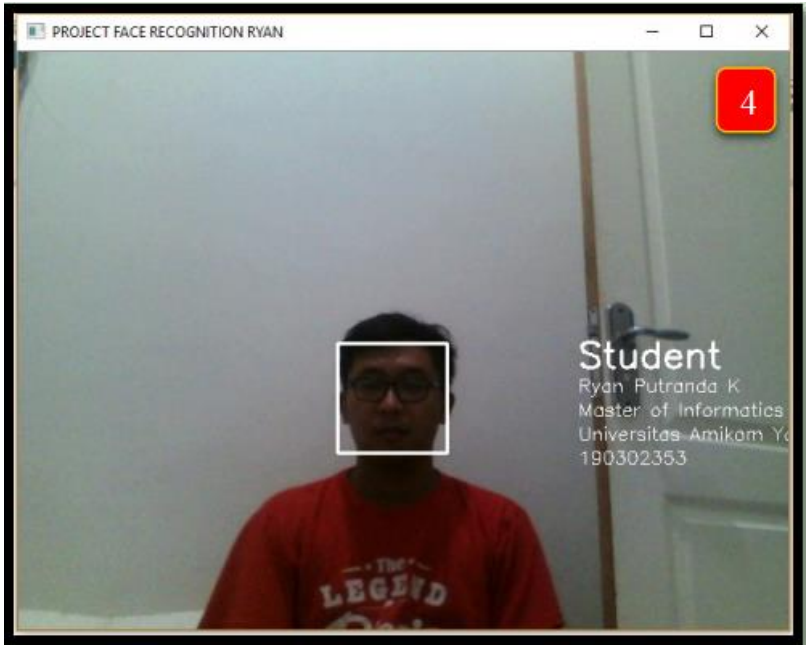

Gambar 8 Tracking dan face recognition dengan jarak $150 \mathrm{~cm}$

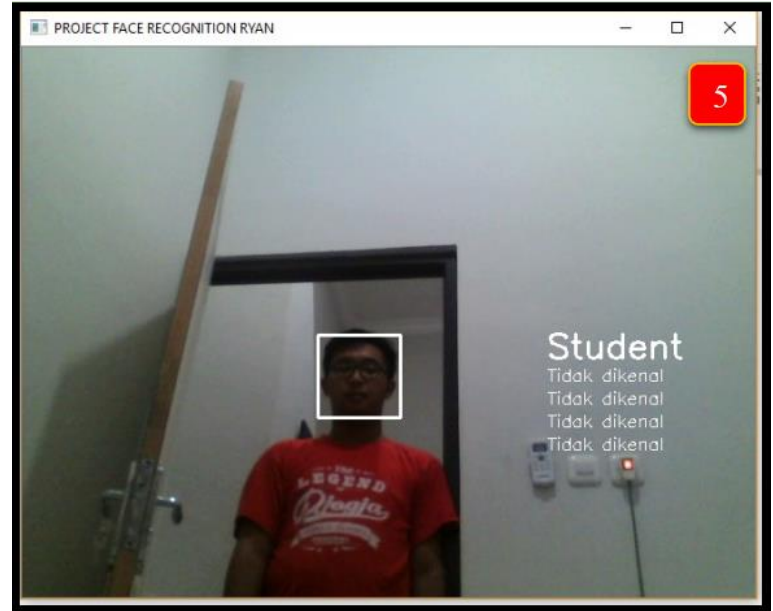

Gambar 9. Tracking dan face recognition dengan jarak $204 \mathrm{~cm}$

\section{KESIMPULAN}

Berdasarkan penelitian yang telah penulis lakukan maka dapat diambil kesimpulan bahwa pendeteksian dan pengenalan objek wajah secara real time untuk kebutuhan presensi perkuliahan mahasiswa mampu menggunakan dengan metode Haar Cascade Classifier beserta Local Binary Patterns Histograms (LBPH). Face Recognition mampu terdeteksi dengan beberapa objek wajah dalam satu frame yang telah terdaftar pada sistem aplikasi presensi, dengan jarak jangkauan optimal face recognition agar terdeteksi sampai $150 \mathrm{~cm}$. Selain itu, Face Recognition tidak berhasil terdeteksi apabila ada obstacle pada wajah dan jarak jangkauan melebihi $150 \mathrm{~cm}$.

\section{REFERENSI}

[1] A. P. Raharjo, A. B. P. Negara, and N. Safriadi, "Sistem Informasi Kehadiran Dosen dan Mahasiswa Menggunakan Sidik Jari pada Program Studi Informatika Universitas Tanjungpura," J. Sist. dan Teknol. Inf., vol. 6, no. 2, p. 76, 2018.

[2] Salhazan Nasution, "PRESENSI ONLINE MENGGUNAKAN RFID PADA KARTU MAHASISWA," Intecoms J. Inf. Technol. Comput. Sci., vol. 1, no. 32, pp. 19-27, 2018.

[3] A. A. Sukmandhani and I. Sutedja, "Face Recognition Method for Online Exams," Proc. 2019 Int. Conf. Inf. Manag. Technol. ICIMTech 2019, vol. 1, no. August, pp. 175-179, 2019.

[4] N. Boyko, O. Basystiuk, and N. Shakhovska, "Performance Evaluation and Comparison of Software for Face Recognition, Based on Dlib and Opencv Library," Proc. 2018 IEEE 2nd Int. Conf. Data Stream Min. Process. DSMP 2018, pp. 478-482, 2018.

[5] M. S. I. Sameem, T. Qasim, and K. Bakhat, "Real time recognition of human faces," ICOSST 2016 - 2016 Int. Conf. Open Source Syst. Technol. Proc., pp. 62-65, 2017. 
[6] R. Lodha, S. Gupta, H. Jain, and H. Narula, "Bluetooth Smart Based Attendance Management System," Procedia Comput. Sci., vol. 45, pp. 524-527, 2015.

[7] S. A. M. Noor, N. Zaini, M. F. A. Latip, and N. Hamzah, "Android-based attendance management system," in 2015 IEEE Conference on Systems, Process and Control (ICSPC), 2015, pp. 118-122.

[8] M. Benny Chaniago and A. Junaidi, "SMS Gateway and barcode technology for presence of students in SMK Unggulan Terpadu PGII Bandung: A case study," Proc. 2016 4th Int. Conf. Cyber IT Serv. Manag. CITSM 2016, pp. 2-5, 2016.

[9] N. Dhanalakshmi, S. G. Kumar, and Y. P. Sai, "Aadhaar Based Biometric Attendance System Using Wireless Fingerprint Terminals," in 2017 IEEE 7th International Advance Computing Conference (IACC), 2017, pp. 651-655.

[10] Z. Vantová, J. Paralič, and V. Gašpar, "Mobile application for creating presence lists," in 2017 IEEE 15th International Symposium on Applied Machine Intelligence and Informatics (SAMI), 2017, pp. 223-228.

[11] G. Chandan, A. Jain, H. Jain, and Mohana, "Real Time Object Detection and Tracking Using Deep Learning and OpenCV," Proc. Int. Conf. Inven. Res. Comput. Appl. ICIRCA 2018, no. Icirca, pp. 1305-1308, 2018.

[12] W. Sriratana, S. Mukma, N. Tammarugwattana, and K. Sirisantisamrid, "Application of the OpenCV-Python for Personal Identifier Statement for Personal Identifier Statement," 2018 Int. Conf. Eng. Appl. Sci. Technol., pp. 1-4, 2018.

[13] A. F. S. Lino, B. C. R. Silva, D. P. C. Rocha, G. P. Furriel, and W. P. Calixto, "Performance of haar and LBP features in cascade classifiers to whiteflies detection and counting," 2017 Chil. Conf. Electr. Electron. Eng. Inf. Commun. Technol. CHILECON 2017 - Proc., vol. 2017Janua, pp. 1-6, 2017.

[14] H. Sharma, S. Saurav, S. Singh, A. K. Saini, and R. Saini, "Analyzing impact of image scaling algorithms on viola-jones face detection framework," 2015 Int. Conf. Adv. Comput. Commun. Informatics, ICACCI 2015, pp. 1715-1718, 2015.

[15] C. Li, Z. Qi, N. Jia, and J. Wu, "Human face detection algorithm via Haar cascade classifier combined with three additional classifiers," ICEMI 2017 - Proc. IEEE 13th Int. Conf. Electron. Meas. Instruments, vol. 2018-January, pp. 483-487, 2017.

[16] X. M. Zhao and C. B. Wei, "A real-time face recognition system based on the improved LBPH algorithm," 2017 IEEE 2nd Int. Conf. Signal Image Process. ICSIP 2017, vol. 2017-Janua, pp. 72-76, 2017. 